\title{
International Business Visits
}

\section{Massimiliano Tani}

$\mathrm{T}$ The notion of migration is typically associated with the idea of a long-term or permanent change of residence. This view arises from both migration policy, which is generally based on the principle of permanent resettlement, and the economic analysis of migration, the labour market effects of which are generally studied using net migration rates (for example, Borjas and Freeman, 1992; Hatton and Williamson, 1994; Barro and Sala-i-Martin, 1995). The emphasis on the 'long-term' is however increasingly at odds with the array of temporary labour movements brought about by globalisation (for example, Ruddock, 2000; Constantin, 2004). With better communication and transportation technologies firms can concentrate key managerial and technical skills in a single location and deploy them to peripheral geographic areas through short-term business trips in lieu of relocations and assignments (for example, Ohmae, 1990; Salt, 1992; Moss-Kanter, 1995). These developments, along with skill-biased technological change, have benefited the highly skilled (for example, OECD, 2002). International business travellers are almost entirely composed of entrepreneurs, professionals, senior government officials, and managers (for example, IATS, 1988; Tani, 2003), and enjoy a wage premium over similarly skilled but not-travelling workers (Anderson, 2002).

Although the economic debate on skilled labour flows in Australia has investigated some forms of temporary migration, it has predominantly focused on movements that last a year or more (for example, Birrell et al, 2001; Hugo, 2002, Wood, 2004). Shorter work-related stays have received little attention. Yet, as Figure 1 illustrates, not only do they make up the bulk of incoming and outgoing movements of workers, but due to the high skill composition of travellers, they are also viewed as a key channel for the international transfer of knowledge (for example, Dosi et al, 1988; Cohen and Levinthal, 1989; Rogers, 1995). In a world where countries fiercely compete for skilled workers and where globalisation expands mobility towards the short-term, the lack of attention on business visits risks missing not only a phenomenon that may be relevant for Australia's economic prosperity, but also the opportunity to understand their effects beyond changes in labour supply.

This paper investigates the economic relevance of short-term business visits for Australia. In particular it studies their relationship with indices of economic growth. The results obtained are analysed vis-⿳亠丷⿵冂- vis those arising from the flows of temporary and permanent migrants. In this paper business visits are defined as labour movements that have a work-related purpose and that last less than 12 months, and the term 'business' is used in a broad sense to mean 'related to work'.

Massimiliano Tani is Senior Lecturer in the School of Business, the University of New South Wales at the Australian Defence Force Academy. 
Four purposes of travel printed on Australian arrival and departure cards form this category: attending a conference, a trade fair, working holiday, and business. The statistics presented include data from all four purposes, unless otherwise specified.

\section{Figure 1: The Gross FlowS OF SKILLED SETTLERS AND BuSINESS VISITORS IN AUSTRALIA: 1991/2-2004/5}

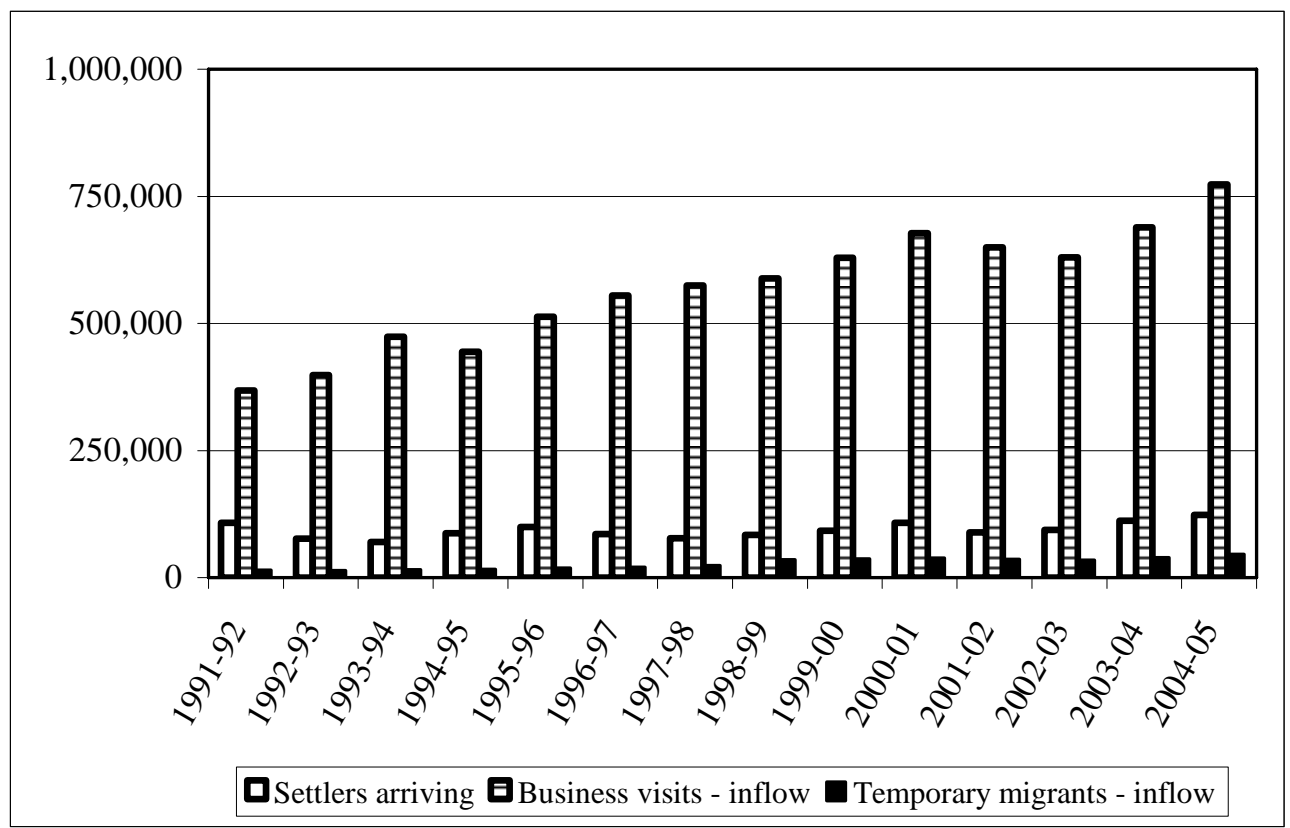

Source: ABS Overseas Arrivals and Departures, (various years)

The chosen 12-month cut-off reflects the conventional length of stay used by the United Nations to separate 'visits' from 'migrations'. Australian statistics use the term visits in a broader sense, and apply 12 months to differentiate between 'short-' and 'long-term' visits. To avoid confusion, 'temporary migration' is used in this paper to mean 'long-term visits' motivated by a 'business' purpose (the four mentioned above). Finally, 'permanent migration' refers to people arriving in Australia with permission for an indefinite stay. 'Skilled migration' is used to identify those admitted under the skilled migration scheme. These definitions will facilitate a comparison of the economic relevance of the various flows.

The rest of the paper is organised as follows: the next section clears some confusion about the definitions of visit and migration, and sets the scene for studying their economic relevance. Some facts about business visits and the characteristics and motivations of travellers are then present. The fourth section illustrates links between business visits, temporary, and permanent migration and some indices of economic growth, followed by an interpretation of the empirical findings and implications for policy. The final section draws some conclusions. 


\section{Definition of Migrations and Visits}

Migration is a movement that entitles the migrant to employment rights in the host country, and it involves a change of residence beyond a certain period of time. At present there is no internationally agreed definition of how long this time should be. Although it is the most commonly used criterion, the length of stay varies among countries. For example, European Union member states use different time cut-offs before registering a new resident, with the result that a person may be concurrently a resident in both the country of origin and destination or of neither (Salt, Singleton and Hogarth, 1994). The United Nations and the International Monetary Fund, respectively, use a 12-month convention to separate migrants from visitors, and to account for earnings abroad as income for the host rather than the sending country. Work-related movements lasting less than a year are reported as business visits. Australian statistics apply the 12 month cut-off to separate short- and long-term visits in the Overseas Arrivals and Departures database (OAD), though 'short-term' is also used for visits lasting less than three months, while 'temporary migration' generally refers to working visas lasting up to four years.

Business visits, like migration, involve a change of residence for reasons connected to one's job, though they give no employment rights in the host country. The distinction between migration and business visits is more than semantic. Governments generally regulate migration flows, even when targeted at particular groups of 'guest workers', but not the flows of business visitors, which tend to be unrestricted. Yet, business visits not only allow workers to fulfil many of the work functions carried out through a temporary resettlement, but they do so at a fraction of migration's administrative formalities, time, and costs.

One of the challenges in developing a study of business visits is to understand whether they are a legitimate form of labour movement rather than a by-product of some other form of international factor and commodity movement. The World Trade Organisation, in the General Agreement for the Trade of Services Mode 4 ('GATS'), argues that several types of labour movements are nothing more than an appendix to an international trade of services, and hence they do not involve any genuine movement of workers. This interpretation is based on the nature of the contractual relations involved. The GATS claims that a labour movement occurring as a result of a contract for the provision of services should be treated as a service (contract for services), and be governed by its legislation. If instead workers move as a consequence of an employment contract (contract of services), then it is a labour flow and it should be regulated by the employment and migration laws of the destination country. Lavenex (2002) describes five broad categories of movements that the GATS considers as part of the international trade of services: (i) business visits of natural persons who maintain residence in their country of origin but move temporarily to negotiate the provision of a service; (ii) movements of natural people following the decision by a foreign firm to establish a branch in the host country; (iii) internal corporate transfers with the same employer; (iv) hiring of specialists who move from a prior employment with a 
service company (Australia and US only); and (v) contractual service suppliers employed by a foreign firm with no local branch (Switzerland and European Union only). The maximum length of stay for these categories varies between up to 90 days for (i) to up to five years for (v). However, due to the practical impossibility of separating contracts for and of service, the GATS allows each country to impose quotas and other restrictions (such as educational qualifications, professional experience, and economic needs tests giving preference to domestic workers), on the same flows that it sets to liberalise, implicitly supporting the idea that they can be viewed as 'true' labour flows (Charnovitz, 2002; Winters, Walmsley, Wang and Grynberg, 2002). This paper builds on this conclusion.

International business visits challenge the way in which economists and policy-makers traditionally study the effects of labour flows: namely through net migration rates in order to measure net additions or reductions to a country's stock of labour. Net migration rates however are not applicable in the case of business visits, as they cause little net change in labour supply. In contrast, business visits seem to affect the stock of knowledge available to a country (for example, Dosi et al, 1988; Cohen and Levinthal, 1989; Rogers, 1995). As the contribution to knowledge of incoming and outgoing workers is unlikely to be identical, it cannot be measured using their net balances. The study of gross rather than net flows of work-related movements seems instead more appropriate in the case of business visits, especially with regards to the possible role played by mobility per se in the formation and diffusion of knowledge. There is an increasing literature documenting the relevance of business visits in processes of knowledge transfers around the world. These include sharing market knowledge between food distributors and farmers to direct production and packaging (for example, Wood, 2001 and the literature cited in it), intra-company production transfers (for example, Slaughter, 2000), as well as visitors' programs in Australian universities to promote the flow of ideas and data analysis between Australia and foreignbased academics and researchers (for example, Hamermesh, 2006), and the existence of funding schemes catering for short-term visits aimed at knowledge exchanges in academia and industry (for example, DEST fellowships for scientific visits, ARC linkage international, Harvard Club of Australia).

\section{Flow of Business Visits}

Figure 2 depicts the flows of business visitors and permanent settlers in Australia throughout the period 1991/2-2004/5 obtained from the OAD database. Six flows are shown. The highest line, starting from over 100,000 persons in 1991/92, shows the gross inflows of settlers at their first entry into Australia. The second line, starting from just over 50,000 person year, is the gross inflow of temporary migrants. These are holders of visa granting employment rights and intending to stay over 12 months to work. This series (and other series, where relevant) is converted into persons-year to adjust for the length of stay (see Anderson, 2002; Tani, 2003). The third line from the top, starting from just below 50,000 personsyear and rising to about 80,000 persons-year in $2004 / 5$, is the corresponding gross 
outflow of temporary migrants. The fourth series, starting from just under 50,000 persons in 1991/2 and dropping for the first three years before rising again, represents the gross inflow of skilled settlers. These are holders of a permanent resident visa granted under Australia's skilled migration program. The fifth and sixth lines at the bottom of Figure 2 show the gross flows of outgoing and incoming business visitors, respectively. Unlike the case of temporary migrants, the outflow of business visitors has been larger than the corresponding inflow throughout the period. The flow patterns of business visitors rise steadily until 2001, after which they show a decline following reduced volumes of travellers and shorter stays post September 11 2001, and the fears of SARS in the Asian-Pacific region in 2003.

Figure 2: Business Visitors and Settlers: Australia, 1991/2-2004/5

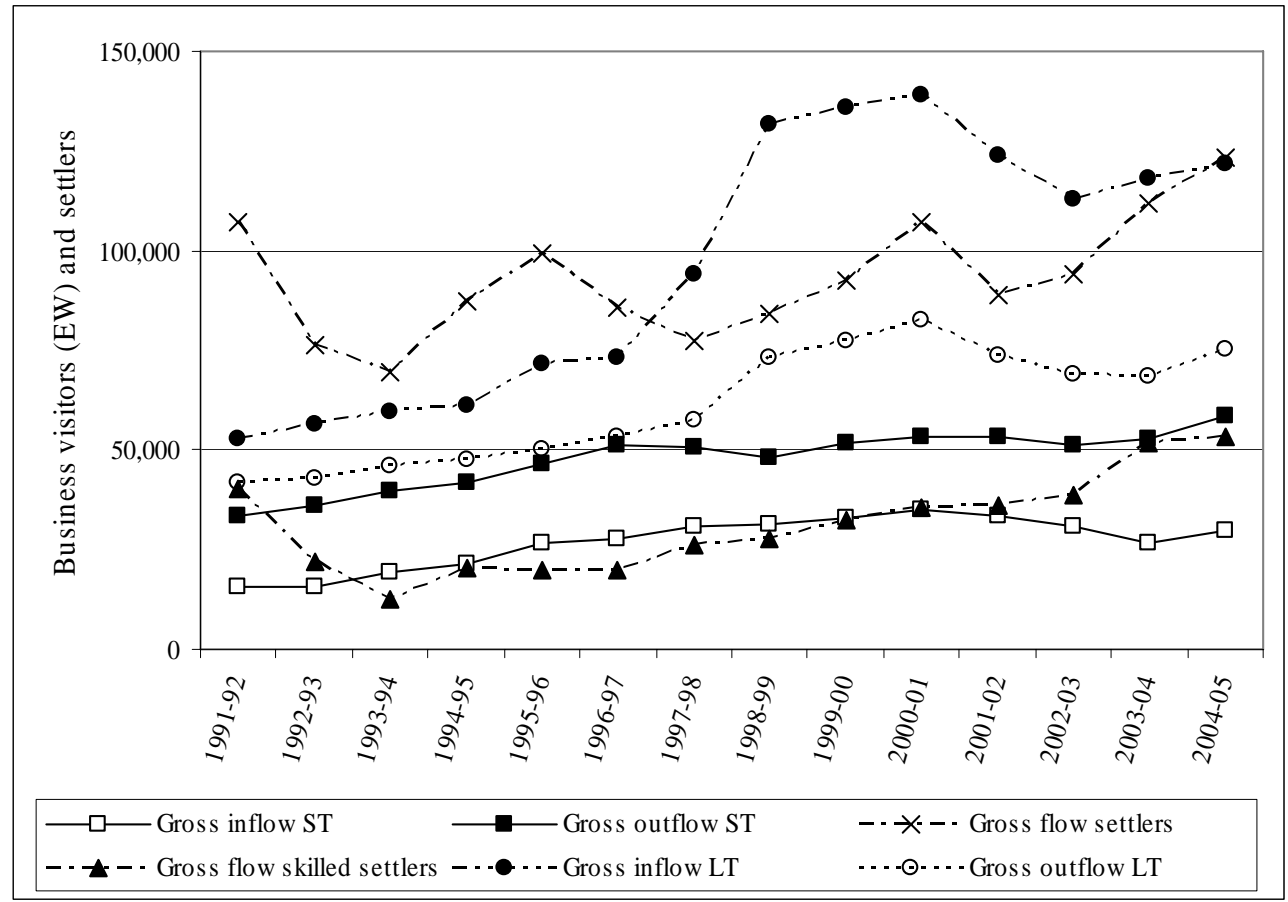

Source: ABS: Overseas Arrivals and Departures, (various years)

The gross annual inflows of business visitors is comparable in size to that of skilled permanent migrants, but smaller than the flows of temporary migrants (see Figure 2). While temporary and permanent migrants have a lasting effect on Australia's endowment of labour, business visitors do not really change Australia's annual headcount of workers. However, their potential economic relevance emerges from data about the motivation of travel. Besides the 
theoretical literature and anecdotal observations, the role of business visits in transferring knowledge across borders draws strength from the answers collected in a survey of business travellers carried out at Sydney airport, whose main results are summarised in Table 1 (Tani, 2005).

Table 1: International Business Traveller Survey: Summary Statistics (Sydney Airport, 2003)

\begin{tabular}{l|lll}
\hline & Inflow & Outflow & Total \\
\hline Personal characteristics & & & \\
\% Males & 89 & 89 & 89 \\
\% Age 45 and above & 53 & 53 & 53 \\
\% Born in Australia and NZ & 41 & 64 & 51 \\
\% University degree or above & 93 & 81 & 89 \\
\% High school only & 7 & 17 & 11 \\
\% Masters degree and PhD & 37 & 32 & 35 \\
\% ISCO 1 and 2 & 98 & 93 & 94 \\
\% Employed in services & 72 & 78 & 74 \\
\% Employed in multinationals & 81 & 51 & 68 \\
\hline Purpose of travel & & & \\
Intra-firm & $40 \%$ & $20 \%$ & $32 \%$ \\
Inter-firm & 35 & 37 & 36 \\
Conference/trade fair & 24 & 38 & 30 \\
Other & 1 & 5 & 2 \\
Functional priority & & & \\
Production and administration & 44 & 31 & 40 \\
Sales and marketing & 18 & 15 & 16 \\
Information and training & 32 & 50 & 39 \\
Other & 6 & 4 & 5 \\
\hline Sample size & 104 & 75 & 179 \\
\hline
\end{tabular}

Source: Tani (2005)

Business travellers are generally males in the age group 35-54, are often born abroad (64 per cent among Australian based travellers), and have a very high level of education: 88 percent have a university or postgraduate degree, while only 11 percent have completed high school. Their educational attainment is considerably higher than the average level of education of the labour force of the host country. 
Table 1 (Outflow) shows that 83 per cent of business travellers have a university degree compared with 33.4 per cent among Australia's labour force (ABS, 2001:23, Table 10).

International business travellers are also highly skilled, based on their occupation, as they are mostly employed in categories 1 and 2 of the International Standard Classification of Occupations (ISCO) which include managers, business owners and professionals. The outflow of business travellers has a higher proportion of entrepreneurs then the corresponding inflow (25 percent vs. 17 percent), and a lower proportion of corporate managers (36 percent vs. 46 percent). The different occupational composition of incoming and outgoing businesspeople is reflected in the purpose of travel. Most business travellers flowing out of Australia go abroad to conferences and trade fairs (38 per cent) or in search of international alliances (37 per cent). Only 20 per cent of the travellers living in Australia visit a company headquarters or a subsidiary, vis-à-vis 40 per cent among incoming businesspeople. With regards to the functional nature of business travel, half of the respondents living in Australia go abroad in search of information or to share knowledge, and to a lesser extent for reasons related to production and administration (31 per cent). In the case of incoming business visitors, the largest proportion comes to Australia for matters internal to the organisation they work for (44 per cent), followed by attending conferences and fact finding (32 per cent). Increasing sales was the least common motivation for travelling for both incoming and outgoing businesspeople, implying that business visits should not really be viewed as an ancillary service to the international trade of commodities and services, as argued by the GATS. For both incoming and outgoing visitors these motivations were declared as being 'typical.'

When the flow of New Zealand residents, who represent over a third of foreign-based respondents, is excluded from the sample, the proportion of foreignbased business travellers visiting subsidiaries and headquarters remains large (36 percent), followed by visits to existing clients (31 percent), and to other firms (16 percent), mainly in order to attend a board meeting. For New Zealand residents, visits to subsidiaries and headquarters in Australia account for 31 percent of the total flows of visitors, followed by information-related visits carried out for training and consulting (28 percent), and visits to existing clients (20 percent).

The large proportion of business travellers responding that their visit was mainly motivated by information and knowledge sharing confirms prima facie the hypothesis that having the ability to interact and exchange knowledge is also relevant to generation of ideas, innovation and economic growth.

\section{Exploring Business Visits, Migration and Growth Links}

As a first step in exploring a possible link between business visits and economic growth, Figure 3 depicts the annual changes in the gross flows of business visitors, temporary and permanent migrants to highlight their relationship. The use of changes rather than levels is intended to eliminate the effects of common trends. 
As illustrated in Figure 3, the annual fluctuations in skilled permanent migration flows take place within a wider band ( \pm 50 per cent) than those of temporary migrants ( \pm 30 per cent) and business visits ( \pm 15 per cent). This result may be symptomatic of the different forces underlying these labour flows, especially with reference to the influence of migration policy. Permanent migration involves the longest length of stay, and, perhaps not surprisingly, it is also the most regulated flow. Temporary migration (average length of stay in Australia: 2.5 years) is also regulated but it is subject to a faster decision process. Finally business visits (average length of stay: 23 days) are unregulated. Throughout the period, business visits are highly correlated to temporary migration (+0.8544), supporting prima facie the hypothesis of substitutability between these two forms of labour movement (for example, Salt, 1992). In contrast, visits and temporary migration are only slightly correlated to skilled permanent migration (coefficients: -0.1341 and +0.0547 , respectively), suggesting viewing the former two as altogether different phenomena from the latter.

Figure 3: Changes in Flows of Business Visits, and Skilled Settlers: Australia, 1991/2-2004/5

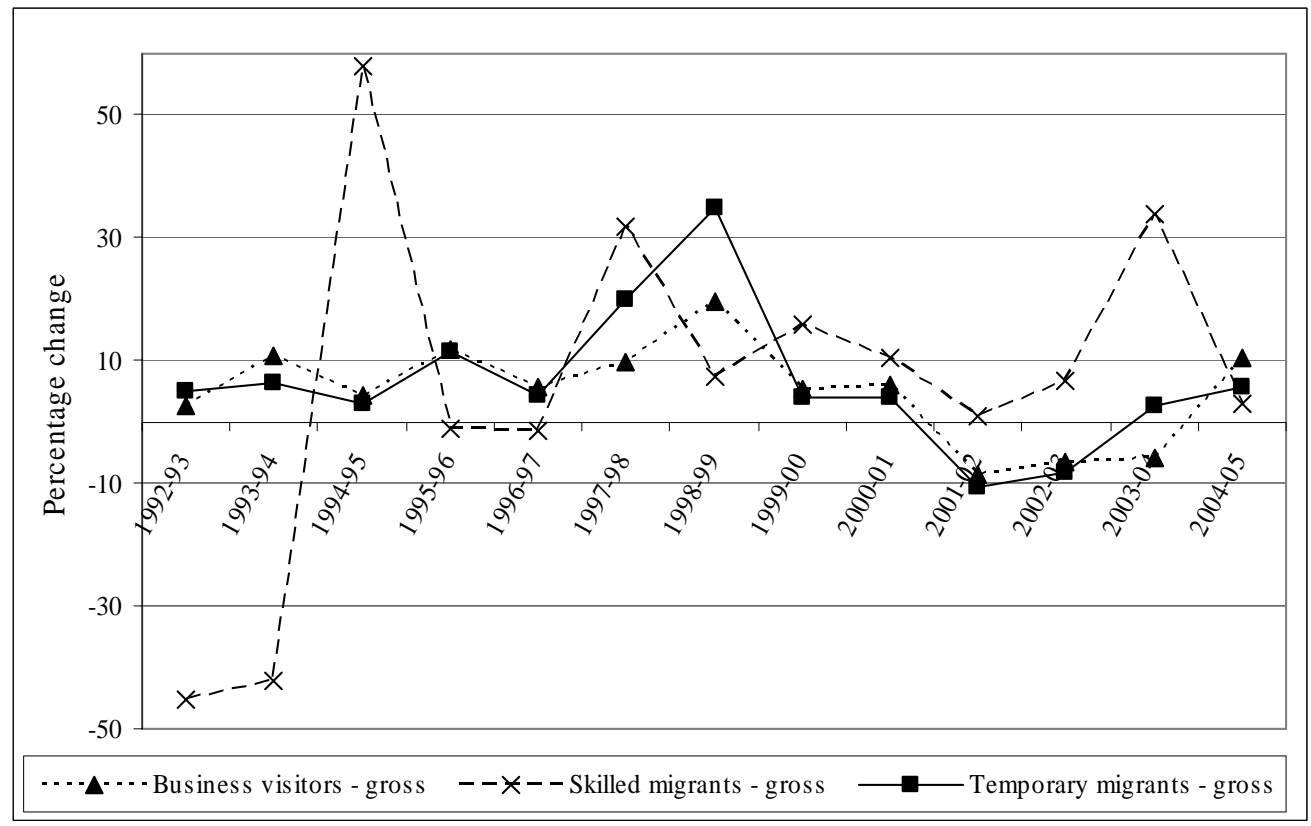

Source: ABS, Overseas Arrivals and Departures Database (various years)

To analyse the economic relevance of each labour flow, their correlations with respect to various indices of economic performance have been calculated, and the coefficients obtained are reported in Table 2. The analysis covers the 
period 1991/2-2004/5, which includes substantial disruptions in international air traffic caused by September 11 and fears of SARS in the first half of 2003. Indicators of economic growth include changes in MFP as well as changes in Australia's output, and input of labour (as measured by changes in working hours), and in input of capital services. The data on Australian changes in productivity, output and input are sourced from the ABS (cat. no. 5204). The flows of migrants and business visitors are obtained from the OAD database.

Table 2 Correlation Coefficients Between Flows of Business Visitors, Temporary and Permanent Migrants, and Growth Indices: Australia, 1991/2-2004/5

\begin{tabular}{|c|c|c|c|c|}
\hline \multirow[b]{2}{*}{ Correlation coefficient } & \multirow{2}{*}{$\begin{array}{l}\text { Productivity } \\
\triangle M F P\end{array}$} & \multirow{2}{*}{$\begin{array}{l}\text { Output } \\
\Delta \text { Output }\end{array}$} & \multicolumn{2}{|c|}{ Inputs } \\
\hline & & & $\begin{array}{l}\triangle \text { Hours } \\
\text { worked }\end{array}$ & $\begin{array}{l}\triangle \text { Capital } \\
\text { services }\end{array}$ \\
\hline \multicolumn{5}{|l|}{ Business visits } \\
\hline$\Delta$ gross flow & 0.1110 & 0.2968 & 0.1587 & 0.3055 \\
\hline$\triangle$ gross flow incoming & 0.2116 & 0.2564 & 0.1153 & 0.0449 \\
\hline$\Delta$ gross flow outgoing & 0.0023 & -0.0083 & 0.1436 & -0.2307 \\
\hline$\Delta$ net flow & -0.1821 & -0.2483 & -0.0414 & -0.2859 \\
\hline \multicolumn{5}{|l|}{ Temporary migration } \\
\hline$\Delta$ gross flow & 0.1921 & 0.4334 & 0.0643 & 0.3959 \\
\hline$\Delta$ net flow & $0.4574 *$ & $0.5633^{* *}$ & 0.0020 & 0.4142 \\
\hline \multicolumn{5}{|l|}{ Permanent migration } \\
\hline$\Delta$ gross flow skilled settlers & -0.1127 & 0.1733 & 0.3351 & 0.3606 \\
\hline$\triangle$ gross flow total settlers & -0.3323 & -0.0012 & 0.3452 & 0.0090 \\
\hline$\Delta$ net flow total settlers & -0.3867 & -0.0154 & 0.3891 & -0.1001 \\
\hline
\end{tabular}

Notes: Level of significance: $*=10$ per cent; $* *=5$ per cent; $* * *=1$ per cent.

Source: ABS cat. 5204.0 (growth indices) and Overseas Arrivals and Departures (visits and migration)

Notwithstanding the difficulty in making statistical inference using only thirteen observations, and the impossibility to test the direction of the causality, the correlation coefficients between the gross flow of business visits and the indices of economic growth are all positive, albeit not statistically significantly different from zero. In particular, they are higher in the case of changes in output $(+0.2968)$ and in capital services $(+0.3055)$ than in the case of changes in MFP $(+0.1110$, the lowest coefficient), and in hours worked $(+0.1587)$. This result suggests that business visits do not really affect the endowment of labour, as they 
are too short. But they may affect the capital available to Australia, most likely through changes in its utilisation rather than net addition to the capital stock, as they are carried out by highly skilled workers who are generally employed in the services sector. Positive contributions to MFP and output growth appear to be more related to inflows of business visitors $(+0.2116$ and +0.2464 , respectively) than to the corresponding outflows $(+0.0023$ and -0.0083$)$, reflecting perhaps that foreign-based businesspeople, who predominantly work for multinational companies and travel to Australia to attend to production and managerial functions (see Table 1 in the previous section), provide new technology and processes.

Temporary migration flows are positively correlated to changes in MFP, output, and capital services, and to a much lesser extent to changes in hours worked. There is little variation between the coefficients obtained using gross and net flows, except for the correlation with changes in MFP, which is higher in the case of net flows $(+0.4574$ versus +0.1921$)$. The correlation between net flows and output is also statistically significantly different from zero.

Skilled permanent migration is strongly correlated to changes in both hours worked and capital services ( +0.3606 and +0.3351 , respectively), but is negatively correlated to productivity (-0.1127), perhaps as a consequence of the lag occurring between immigrating and taking up work (for example, Richardson et al, 2001), or the possible mismatch between the immigrant's skills and the occupation found in Australia. Unlike skilled migrants, the overall flow of permanent migrants seems to contribute mainly to manpower, as both gross and net flows are positively correlated with changes in the hours of work $(+0.3452$ and +0.3897 , respectively), but are negatively correlated with the other indices of economic performance.

When the results are read across the three different types of labour flows, business visits do not appear to be so significantly different to temporary migration to justify their exclusion from the current debate on brain gains and drains: the size and the sign of the correlation coefficient of the gross flows of visitors are in line with those obtained from the flow of temporary migrants (all indices) and skilled permanent migrants (output).

Restricting the flow of business visits to travel made strictly for 'business', thereby eliminating trips due to conferences, trade fairs and working holidays, which may activities not strictly devoted to work, generally strengthens the correlation, but the coefficients remain statistically insignificantly different from zero, When the analysis is carried out over a longer period of time but limited to the years prior to September 11, the correlation between the gross flow of visitors and changes in MFP, output, and hours worked, are all statistically significantly different from zero, as shown in Table 3. Interestingly, post September 11, international business telecommunications seem to have taken off (OECD, 2005:Table 3.8; 4.2), but the data available are too limited to test whether there has been a direct substitution between visits and communication via internet and videoconferencing. 
Table 3: Correlation Coefficients between the Flows of Visitors Strictly for Business and Growth Indices - Australia, 1976/7-2001/2

\begin{tabular}{l|cccc}
\hline Correlation coefficient & $\begin{array}{c}\text { Productivity } \\
\triangle M F P\end{array}$ & $\begin{array}{c}\text { Output } \\
\triangle \text { Output }\end{array}$ & $\begin{array}{c}\text { Inputs } \\
\Delta \text { Hours } \\
\text { worked }\end{array}$ & $\begin{array}{c}\Delta \text { Capital } \\
\text { services }\end{array}$ \\
\hline Business visits pre-9/11 & & & & \\
\ gross flow & $0.3897^{* *}$ & $0.5175^{* * *}$ & $0.5118^{* * *}$ & 0.0319 \\
$\Delta$ net flow & 0.1244 & 0.1206 & 0.0758 & 0.0512 \\
$\Delta$ gross flow incoming & 0.2867 & $0.4011^{* *}$ & $0.4160^{* *}$ & 0.0064 \\
$\Delta$ gross flow outgoing & $0.3415^{*}$ & $0.4304^{* *}$ & $0.4044^{* *}$ & 0.0421 \\
\hline
\end{tabular}

Notes: Level of significance: $*=10$ per cent; $* *=5$ per cent; $* * *=1$ per cent.

Source: ABS cat. 5204.0 (growth indices) and Overseas Arrivals and Departures (extraction on 'strict' business visits).

Table 3 also shows that over the period 1976/7-2001/2 the correlations between the gross outflow and MFP and output are stronger and larger than those obtained on the corresponding inflows, against the results reported in Table 2 . This result may reflect compositional and motivational differences between Australian-based travellers, who are often small business owners and professionals travelling abroad to gain and share knowledge and hence may be more prone to bring back new ideas and innovations, than foreign-based businesspeople, who tend to operate within their employers' range of activities.

Among the alternative measures of business visits reported in Table 2 and in Table 3, the gross flow emerges as consistently having higher correlations to productivity and output than the net flow. The stark contrast of the correlations obtained on gross and net flows appears indicative of the mismatch between trying to measure the economic relevance of a short-term phenomenon (business visits) using an instrument that measures a long-term effect (net change in labour supply). This result suggests that the economic effects of business visits ought to be studied with a different approach, away from the focus on net changes in factor endowments. On the one hand it is probably true that a temporary labour movement 'has none of the cultural, social or political dimensions that are associated with international migration because it explicitly does not entail shifts in residence. However, its direct economic consequences can be thought of as those of migration. Workers enter a country temporarily to carry out particular jobs and thus labour inputs in one economy are reduced while those in another are increased' (Winter, 2002:6). On the other hand, this approach to modelling the economic effects of temporary labour flows is of limited use to the analysis of business visits, as it does not account for the flow of knowledge that seems to 
motivate many trips. It is however possible to extend existing models to include knowledge as a contributor to growth, as discussed below.

\section{An Interpretative Framework for Gross and Net Labour Flows}

The relationship between gross flows of visitors and output growth shown in Table 2 can be formally captured in a simple growth model by considering the knowledge exchanged through business trips as an externality to a country's production function (see Tani, 2007). This approach suggests that labour flows affect an economy through two distinct mechanisms. The first, which is typical of migration, is a temporary change in labour input in both countries of origin and destination, as skills are embodied in people and move with them (embodied effect). This effect is proportional to the net flows of visitors insofar as leaving the country causes a skill loss in the place of origin and a corresponding gain in the place of destination. There is no embodied effect when workers only move temporarily without provoking a change in domestic supply of skills. The second mechanism is a contribution to knowledge arising from participating in the flow of ideas and technology continuously developed around the world. This effect can be modelled as an externality affecting all factors of production, as innovations in the use of a factor are likely to enhance the efficiency levels of the other factors used in production. The externality arises because of labour mobility per se: the higher the number of workers exchanging information and ideas, and the higher the frequency of their movements, the higher their knowledge contribution (disembodied effect). As a result, it relates to gross rather than net labour flows. The disembodied effect operates differently for migrants and visitors: the knowledge contribution of the former is high after arrival, but it fades as time goes on, assuming no further movement. For the latter it is directly related to the frequency of their international movements. Changes in migration flows operating through the embodied effect mostly produce changes in the endowments of skills in both countries of origin and destination, and affect a country's capital depletion. The disembodied effect, by raising a nation's stock of knowledge, operates through changes in capital accumulation. In particular, as long as there is a flow of visitors, a country enhances its ability to innovate.

For policy-makers this theoretical framework strengthens the provision of policies aimed at temporary movements, as Australia has implemented in recent times. This may affect the nature of the international competition for skilled labour among countries. A policy favouring the arrival of foreign business visitors, such as improved domestic transport infrastructures or academic visitors' programmes is expected to raise the stock of knowledge and hence the available capital. This would always have a positive impact on the host country's rate of growth, and vice-versa. In contrast, a policy favouring the temporary outflows of domestic workers, such as participating to a collaborative international research program based abroad, would raise both capital accumulation through the inflow of ideas upon return, and reduce the knowledge per effective worker ratio due to 
the temporary net loss of skilled domestic labour. A positive effect on growth would occur only when the disembodied effect outweighs the embodied effect.

Unlike the international competition for skilled permanent migrants, which is often a zero sum game where the headcount gains for a country are losses for another, business visits actually benefit both sending and receiving countries by enhancing their stock of knowledge. Even with a zero net change between in- and out-flows of business visitors, sending and receiving countries still experience positive contributions to their domestic knowledge stock. Better microeconomic data and more research would be needed test more rigorously this hypothesis, and to ascertain whether an optimum level of international mobility exists.

\section{Final Remarks}

This paper highlights that in a globalised world the convention that separates between visits and migration based on the length of stay has no economic justification, as both visits and temporary migration are similarly correlated to measures of growth. The greatest danger for economic analysts and policymakers is to continue focusing on migration without questioning and investigating the nature of business visits. These are not only an opportunity to 'show the country' before a long-term commitment is made, but can involve knowledge diffusion even when non-economic reasons (such as, family, quality of life, habits) prevent people from resettling. Acknowledging that ideas travel with people, irrespective of their length of stay, can enhance a country's edge in international competition for skilled workers, particularly for a geographically disadvantaged country such as Australia. More research on business visits is called for. The preliminary empirical evidence discussed in this paper indicates that the large volume of skilled workers that, thanks to modern means of transportation, can move across borders without changing residence may contextualise some of the concerns raised by the current debate on Australia's brain gains and drains.

\section{References}

Anderson, E. (2002), 'Skilled Worker Mobility and International Inequality’, Unpublished mimeo, University of Sussex.

Australian Bureau of Statistics (2001), Education and Training Experience, cat. no. 6278.0, Canberra.

Barro, R. and X. Sala-I-Martin (1995), Economic Growth, McGraw-Hill, New York.

Birrell, B., I. Dobson, V. Rapson and T. Smith (2001), 'Skilled Labour: Gains and Losses', Centre for Population and Urban Research, Melbourne, Monash University.

Borjas, G. and R. Freeman (eds) (1992), Immigration and the Work Force, University of Chicago Press, Chicago (for National Bureau of Economic Research).

Charnovitz, S. (2002), 'WTO Norms on International Migration', Paper presented at the IOM Workshop on Existing International Migration Law Norms, April 30 ${ }^{\text {th }}$, Geneva. 
Cohen, W. and D. Levinthal (1989), 'Innovation and Learning: The Two Faces of R\&D', Economic Journal 99(397):569-596.

Constantin, F. (2004), 'Migrating or Commuting? The Case of Romanian Workers in Italy: Niches for Labour Commuting to the EU', www.eumap.org/journal/features/2004/ migration/commuting/, accessed $10^{\text {th }}$ October 2006.

Dosi, G., C. Freeman, R. Nelson, G. Silverberg, and L. Soete (eds) (1988), Technical Change and Economic Theory, Maastricht Economic Research Institute on Innovation and Technology, International Federation of Institutes for Advanced Study Research Series, No. 6, Pinter, London.

Hamermesh, D. (2006), 'The Value of Peripatetic Economists: A Sesqui-difference Evaluation of Bob Gregory', Economic Record 82(257):138-149.

Hatton, T. and W. Williamson (eds), (1994), Migration and the International Labor Market, 1850-1939, Routledge, London.

Hugo, G. (2002), 'Migration Policies Designed to Facilitate the Recruitment of Skilled Workers in Australia', pp 291-320 in OECD, International Mobility of the Highly Skilled, Paris.

International Air Travel Survey (1988), The European Frequent Business Traveller, European Data and Research Limited, Henley on Thames.

Lavenex, S. (2002), 'Labour Mobility in the General Agreement on Trade in Services (GATS)', Unpublished mimeo, University of Bern.

Moss Kanter, R. (1995), World Class, Simon \& Shuster, New York.

Ohmae, K. (1990), The Borderless World, Harper Business, London.

OECD (2005), Communications Outlook, Paris.

OECD (2002), International Mobility of the Highly Skilled, Paris.

Richardson, S., F. Robertson and D. Ilsey (2001), 'The Labour Force Experience of New Migrants’, Department of Immigration, Multicultural and Indigenous Affairs, Canberra.

Rogers, M. (1995), 'International Knowledge Spill-Overs: A Cross-Country Study', pp. 166-188 in S. Dowrick (ed.), Economic Approaches to Innovation, Edward Elgar Publications Aldershot, UK.

Ruddock, P. (2000), 'Australian Immigration in a 'Dot Com' World', Australian Economic Review 33(3):257-261.

Salt, J. (1992), 'Migration Processes among the Highly Skilled in Europe', International Migration Review 26(2):484-505.

Salt, J., A. Singleton, and J. Hogarth, (1994), 'Europe's International Migrants: Data Sources, Patterns and Trends’, HMSO, London.

Slaughter, M. (2000), 'Production Transfer within Multinational Enterprises and American Wages', Journal of International Economics 50:449-472.

Tani, M. (2003), 'International Business Travel and Australia Skills’ Endowment', Agenda 10(3):248-259. 
Tani, M. (2005), 'On the motivations of business travel: evidence from an Australian survey’, Asian and Pacific Migration Journal 14(4):419-440.

Tani, M. (forthcoming, 2007), 'Short-term Skilled Labour Movements and Economic Growth’, International Migration.

Winters, L. (2002), 'The Economic Implications of Liberalising Mode 4 Trade', Joint WTO-World Bank Symposium on the Movement of Natural Persons (Mode 4) Under the GATS, WTO Geneva, 11-12 April.

Winters, L., T. Walmsley, Z. Wang, and R. Grynberg (2002), 'Negotiating the Liberalisation of the Temporary Movement of Natural Persons', Discussion Paper 87, Sussex University, October.

Wood, A. (2001), 'Globalisation and Wage Inequalities: A Synthesis of Three Theories', Weltwirtschaflisches Archiv 138(1):54-82.

Wood, F. (2004), 'Beyond Brain Drain’, Workshop Report, Centre for Higher Education Management and Policy, Armidale, University of New England.

This paper is part of a research project funded by ARC grant no. LP 0561107, and the Department of Immigration, Multicultural, and Indigenous Affairs (DIMIA). I thank S. Dowrick, K. Sharpe, J. P. Cassarino, two anonymous referees and Graeme Wells for comments and suggestions. A very special thanks goes to the statistics section of DIMIA for valuable help with the data. The usual disclaimer applies. 